\title{
A Systematic Literature Review for the Recycling and Reuse of Wasted Clothing
}

\author{
Xiufen Xie ${ }^{1}$, Yan Hong ${ }^{1, * \mathbb{C}}$, Xianyi Zeng ${ }^{2}{ }^{\mathbb{D}}$, Xiaoqun Dai $^{1}$ and Melissa Wagner $^{3}$ \\ 1 College of Textile and Clothing Engineering, Soochow University, Suzhou 215031, China; \\ 20194215046@stu.suda.edu.cn (X.X.); daixqsz@suda.edu.cn (X.D.) \\ 2 École Nationale Supérieure des Arts et Industries Textiles, 30329 Roubaix, France; xianyi.zeng@ensait.fr \\ 3 Independent Researcher, Loughborough LE11 3TU, UK; melissamwagner1@gmail.com \\ * Correspondence: hongyan@suda.edu.cn
}

Citation: Xie, X.; Hong, Y.; Zeng, X.; Dai, X.; Wagner, M. A Systematic Literature Review for the Recycling and Reuse of Wasted Clothing. Sustainability 2021, 13, 13732. https:// doi.org/10.3390/su132413732

Academic Editor: Abbas Mardani

Received: 23 November 2021

Accepted: 7 December 2021

Published: 13 December 2021

Publisher's Note: MDPI stays neutral with regard to jurisdictional claims in published maps and institutional affiliations.

Copyright: (c) 2021 by the authors. Licensee MDPI, Basel, Switzerland. This article is an open access article distributed under the terms and conditions of the Creative Commons Attribution (CC BY) license (https:// creativecommons.org/licenses/by/ $4.0 /)$.

\begin{abstract}
With the growing frequency and quantity of clothing purchases, the elimination rate of waste clothing is increasing. Many researchers have contributed to the topic of the recycling and reuse of waste clothing, and therefore many related literature reviews are emerging. The current reviews only focus on waste textile recycling and waste-clothing life-cycle evaluation. The topic of wasteclothing recycling itself is ignored. In this article, we propose a systematic review of the recycling and reuse of wasted clothes. Firstly, we summarize the existing methods of waste-clothing collection and recycling and the related recycling technology, and discuss their advantages and disadvantages. The involved literatures are journal articles, book chapters, and conference papers selected from Google Scholar and Web of Science. Citespace software, as a literature visualization tool is used for the analysis. Based on this review, the low efficiency of waste-clothes recycling can be attributed to poor organization from a management aspect. From a consumer perspective, because of the differences in understanding among consumers about waste-clothing recycling, the existing clothingrecycling system cannot be fully utilized. The results of this review provide reference for further research on waste-clothing recycling, and make suggestions for the relevant governmental/industrial development strategies.
\end{abstract}

Keywords: waste clothing; recycling; sustainability; fashion

\section{Introduction}

Recently, driven by the fast fashion trend, the consumption of clothing has increased greatly. Subsequently, the quantity of waste clothes has also increased. The waste-clothing recycling mentioned in this paper includes the recycling of consumers' obsolete clothing, and the recycling of inventory clothing. Based on the report of the Waste and Resources Action Programme (WRAP), the amount of clothing consumed in the UK in 2016 was 3.6 million tons, a 16\% increase compared with 2012 [1]. The carbon footprint of British clothing rose from 24 million tons in 2012 to 26.2 million tons in 2016. The greenhouse gas emissions created by consuming 336 tons of clothing is equal to driving a car for 6000 miles in the UK [2]. Thus, it is obvious that waste clothing causes both environmental and ecological problems.

Based on the research of the Waste and Resources Action Programme (WRAP), the lifetime of garment utilization in the UK is 3 years on average [1]. The environmental impact created by waste clothing could be significantly reduced if it were possible to extend the lifetime of garment utilization [3]. According the report of the Sustainable Clothing Action Plan (SCAP), the carbon, water, and waste footprint of clothing consumption could be reduced by $10-20 \%$ if we changed the way clothing is supplied, used and disposed of in the UK [4]. Therefore, the appropriate utilization and disposal of waste clothing can effectively reduce its negative impact. 
However, as clothing is made of different fabrics and accessories with different types of raw materials, disposed waste clothing becomes a very complicated problem. This is because the processing of different types of raw materials are very different. Improper disposal of waste clothing will cause greater problems. A Danish mass flow analysis of clothing and household textiles from 2010 estimated that total Danish consumption was $16 \mathrm{~kg}$ per person, per year. This corresponds to fact that 24,000 tonnes of clothing and household textiles are incinerated annually, i.e., about $1.7 \%$ of the total amount of residual waste incinerated in 2011 [5]. According to the United Nations website, the fashion industry (clothing and footwear) produces more than $8 \%$ of the global greenhouse gases and $20 \%$ of the wastewater produced annually [6]. The existing means of disposal for waste clothing include discarding, burning, recycling, reuse, etc. Among these methods, it has been proven that the recycling and reusing method is the most effective disposal method, with the least impact on the environment.

Furthermore, the recycling of waste clothing is an independent topic, separate from the recycling of waste textiles. Many researchers are contributing to the recycling of waste textiles and its reuse. Related works around the recycling of waste textiles are as follows: (1) waste textile recycling, including the recovery and recycling of waste textiles. For example, Wagner et al. explored recycled textiles and the perceived behaviors of consumers, manufacturers, brands, and designers towards reuse [7]. Walter et al. have analyzed the present trends on textile recycling, the obstructions which are impeding greater recycling, and outlined the socio-economic advantages of moving towards a circular economy [8]. Sandin et al. reviewed the research status of the environmental impact of textile reuse and recycling, provided a summary of the current knowledge, and identified further research directions [9]. Hole et al. summarized and discussed the eco-friendly achievements within the development of the textile industry, dealing with three main contributors: production, consumption and recycling [10]. (2) Life-cycle research deals, regarding the ways by which waste textiles return to the fashion system, in an innovative approach. Rotimi et al. reviewed the existing literature on the sustainable development of the fashion industry supply chain, established sustainability practices, managed postconsumer textile waste (PCTW), and demonstrated strategic competitive advantages at the end of the garment life cycle, with four practices [11]. When analyzing the present literature reviews, we noticed that existing researchers have ignored waste-clothing recycling itself, especially with regards to its complexity. The complexity here refers to the rationality of waste-clothing recycling and its classification, and the management of waste-clothing recycling and reuse. The recycling of waste clothing itself is also an important way to realize environmental responsibility and circular economy.

To solve these problems, we propose in this article a systematic review around the existing research on waste-clothing recycling and reuse. Citespace software was used to analyze the research trend of relevant articles on waste-clothing recycling and reuse. The classification of waste clothing, recycling mode and recycling technology were analyzed and summarized. Firstly, relevant research papers on waste-clothing recycling and reuse were retrieved through the Web of Science (WOS) database and Google Scholar. Secondly, the current recycling mode, classification and recycling technology of waste clothing and its reuse were summarized. Since Citespace can only analyze articles in the WOS Core Database, in addition to the articles in the WOS Core Database, we included other related articles for analysis. Citespace software was used to cluster and analyze the keyword research topic-trend spectrum of waste-clothing recycling and reuse related articles. Based on the trend of research topics and the number of publications, the social value and market value of the recycling scheme of waste-clothing recycling and reuse were analyzed, and the advantages and disadvantages of waste-clothing recycling technology were analyzed and recapitulated. Compared with existing similar reviews, this article provides a systematic review of waste clothing from the perspective of recycling waste clothing itself. It enriches the blank field review relating to the recycling of waste clothing. 
This paper is comprised of five chapters. The first chapter is the introduction, which analyzes the background and research ideas of waste clothes. The second chapter is the analysis of waste-clothes recycling, including the recycling mode, policy, recycling category, and treatment technology. The third chapter is an extension of Chapter 2. Citespace software was utilized to cluster the related literatures, based on the hot research keywords on waste-clothing recycling. The fourth chapter summarizes and discusses the content of the first two chapters, summarizes the social and market value of waste-clothing recycling from the perspective of environmental responsibility and circular economy from the perspective of enterprises, governments and consumers, and puts forward the shortcomings of research and suggestions for future research. The fifth chapter is the conclusion, which summarizes the content of the whole article.

\section{Waste-Clothing Recycling and Its Mode, Classification and Treatment}

We searched the existing literatures on waste-clothing recycling in the Web of Science (WOS) and Google Scholar databases, and analyzed the current situation of waste-clothing recycling from the perspective of environmental responsibility and circular economy, including the recycling mode, classification and processing technology.

\subsection{The Mode of Waste-Clothing Recycling}

According to the existing literature, the current recycling modes can be summarized as internet-based recycling, brand-led recycling, and government-led recycling.

\subsubsection{Internet-Based Recycling}

Internet-based recycling uses the internet to create a platform to recycle waste clothes. Its business mode is that users make recycling requests online at different terminals (websites or applications), and persons who are responsible for the collection of waste clothing will come to take these garments [12]. Its advantages are convenience, speed, and efficiency. Many researchers have studied this recycling method. Zhang et al. mentioned in their study that the online clothing-recycling platform (OCRP) has now emerged as a new channel for the disposal of leftover clothing; however, fewer than $10 \%$ of respondents deem the OCPR as one of their major channels to handle waste clothes [13]. Some researchers are also making contributions from the field of artificial intelligence technology, and how this can be integrated into these recycling systems. For example, Zhou et al. designed a smart incentive-based recycling system by the Internet of Things and data analysis technologies, which strengthened the recycling of waste clothing through information sharing among various components [14]. Li et al. elaborated that waste protective clothing should be recycled through the combination of internet recycling and intelligent recycling [15]. Claudio et al. studied the cases of consumers selling used clothes directly to others on auction websites based on the internet model [16].

Based on the above literature, it can be seen that the described online platform and the intelligent recycling of waste clothing make recycling both more economical, and environmentally friendly. Nevertheless, the operation of internet-based terminals (websites or applications) is sometimes a challenge for elderly people.

\subsubsection{Brand-Led Recycling}

Compared with the internet-based model, brand-led recycling is accepted by more users, without many limitations. The brand-led mode has two forms: fashion brands extend their services and take responsibility for the recycling themselves; or, specific recycling brands will oversee waste-clothing recycling (see Table 1). In the first form, fashion brands will build recycling channels and carry out recycling-related business, and the reuse of recycled clothing [17]. For example, H\&M recycles jeans after consumption, to make new clothes and new products [17]. In the second form, recycling companies show the public where the waste clothes will go, to increase public trust. For instance, the "Blue Jeans Go Green" plan proposed by Madewell takes waste jeans and reuses them 
as insulation materials [17]. In textile recycling, a multitude of participants can be found on the international stage, and despite some technical, social and economic challenges, dissimilar brands have started to invest in textile recycling (see Table 2), improving the life cycle of garments while saving energy [18-21].

Table 1. Summary of recycling companies that utilise waste-clothing recycling, and their reuse cases.

\begin{tabular}{cc}
\hline Recycling Company & Project \\
\hline Reuse Fabric Bank (RFB) & $\begin{array}{r}\text { Users get points for storing waste materials, such as discarded } \\
\text { clothes, which are cleaned and disinfected by the bank and } \\
\text { re-circulated in the market. The points earned by users can be used to } \\
\text { buy textile materials they need at the bank [8]. }\end{array}$ \\
\hline $\begin{array}{c}\text { Bank of Clothing from } \\
\text { Caxias-doSul (BCCS) }\end{array}$ & $\begin{array}{r}\text { The bank centrally stores textile waste from factories in the area. } \\
\text { Reriving waste from the local textile industry, various materials are } \\
\text { system, which continue to use these materials [22]. }\end{array}$ \\
\hline TEXAID & $\begin{array}{r}\text { The post office regularly delivers bags for residents to recycle waste } \\
\text { clothes, and the company sends specialists from nearby stations to } \\
\text { collect them [23]. }\end{array}$ \\
\hline Trans-America & $\begin{array}{c}\text { About 30\% of its used textiles are used for industrial purposes: } \\
\text { between } 25-30 \% \text { are recycled into fibres for use as stuffing for } \\
\text { upholstery, insulation, and the manufacturing of paper products, and } \\
\text { about 45\% of textiles continue their life as clothing [16]. }\end{array}$ \\
\hline
\end{tabular}

Table 1 summarizes the reuse cases of waste-clothing recycling. According to Table 1 , recycling company's management of various waste clothing has greatly promoted wasteclothing recycling and reuse.

Table 2. Summary of fashion brands and their recycling projects.

\begin{tabular}{|c|c|}
\hline Brand & Project \\
\hline American Eagle & $\begin{array}{l}\text { Company website online promotion; consumers can save } \$ 10 \text { on new jeans } \\
\text { by recycling waste jeans [17]. }\end{array}$ \\
\hline \multirow{2}{*}{$\mathrm{H} \& \mathrm{M}$} & $\begin{array}{c}\text { Recycling boxes: consumers will receive } 15 \% \text { off their purchase for } \\
\text { donating; for every bag donated, consumers will receive a double reward } \\
\text { of two coupons. Significantly, } 95 \% \text { of all clothes that get thrown away } \\
\text { could be reused or recycled [17]. }\end{array}$ \\
\hline & $\begin{array}{c}\text { The brand collects recycled fibres such as cotton, wool and cashmere from } \\
\text { pre - and post-consumption waste to make clothing, and if a product } \\
\text { contains fibres from used clothing, it provides consumers with this } \\
\text { information on the label [18]. }\end{array}$ \\
\hline Madewell & $\begin{array}{c}\text { Put forward the nursing method of denim; consumers are encouraged to } \\
\text { bring a pair of 'pre-loved' jeans to the store and get } \$ 20 \text { off new jeans. } \\
\text { Come up "The Blue Jeans Go Green" programme to turn the denim into } \\
\text { insulation [17]. }\end{array}$ \\
\hline The North Face & $\begin{array}{c}\text { Emphasis on clothing being used before being discarded. } \\
\text { They are in partnership with the nonprofit organisation Soles4Souls. } \\
\text { Company publicity key points are on the lifecycle of clothing and other } \\
\text { goods [17]. }\end{array}$ \\
\hline $\begin{array}{l}\text { Egetpper } \\
\text { (Denmark) }\end{array}$ & $\begin{array}{l}\text { The brand has set up a recycling system, using recycled fishing nets to } \\
\text { make carpets [18]. }\end{array}$ \\
\hline Houdini (Sweden) & $\begin{array}{l}\text { The company collects waste products from consumers, and } 100 \% \text { of the } \\
\text { waste polyester products are sent to the factory for recycling. The company } \\
\text { uses nylon and polyester materials extracted from PET bottles to make } \\
\text { clothes [18]. }\end{array}$ \\
\hline
\end{tabular}


Table 2. Cont.

\begin{tabular}{cc}
\hline Brand & Project \\
\hline Lindex (Sweden) & The company uses recycled denim in its new denim collection [18]. \\
\hline Nortex (Denmark) & $\begin{array}{r}\text { The brand uses pre-consumer textile waste and recycled PET fibres from } \\
\text { used plastic bottles to make its fibres. } \\
\text { The brand's designers use clothing accessories as little as possible [18]. }\end{array}$ \\
\hline Uniqlo & $\begin{array}{r}\text { The company recycles all goods and clothes that customers no longer need, } \\
\text { and donate them to refugee camps around the world; waste clothing, } \\
\text { which can no longer be used, is recycled as fuel and fibre [19,20]. }\end{array}$ \\
\hline Top Shop & The brand's new offerings are redesigns of used clothing [21]. \\
\hline
\end{tabular}

Table 2 summarizes the different cases of various brands carrying out waste-clothing recycling projects. Through waste-clothes recycling and its further reuse for sales, clothes will be prevented from becoming pollution and the effect on the environment will be reduced. This will also increase the interactions between brands and consumers, improve the participation of consumers, and increase consumers' awareness of waste-clothing recycling.

\subsubsection{Government-Led Recycling}

Taking into consideration environmental responsibility and circular economy, the government also takes actions for waste-clothing recycling and reuse [24]. These actions are always about the policy aspect. Governments of different countries have already released different policies about this (Table 3). Governmental support has greatly promoted the waste-clothes recycling work.

Table 3. National government laws on recycling waste textiles and clothing.

\begin{tabular}{|c|c|c|}
\hline Countries & Policy & Content/Influence \\
\hline \multirow{2}{*}{$\begin{array}{l}\text { European } \\
\text { Union }\end{array}$} & Waste grading system [25] & $\begin{array}{l}\text { It provides clear guidance for environmentally friendly } \\
\text { textile waste treatment. }\end{array}$ \\
\hline & Circular economy plan [26] & $\begin{array}{l}\text { Member states must introduce extended producer } \\
\text { responsibility (EPR) policies. }\end{array}$ \\
\hline France & $\begin{array}{l}\text { EPR policy to manage textile } \\
\text { waste [27] }\end{array}$ & $\begin{array}{c}\text { France is the only country in the world implementing an } \\
\text { extended producer responsibility (EPR) policy for } \\
\text { end-of-use clothing. }\end{array}$ \\
\hline Germany & $\begin{array}{l}\text { Circular economy and Waste } \\
\text { Management Law }[28,29]\end{array}$ & "Avoid generating recycled final disposal". \\
\hline \multirow[b]{2}{*}{ Britain } & Zero waste economy [29] & $\begin{array}{l}\text { Waste fabrics are regarded as recyclable and reusable } \\
\text { resources }\end{array}$ \\
\hline & $\begin{array}{l}\text { "Landfill allowance Trading } \\
\text { scheme" [30,31] "Waste and } \\
\text { Resources Action Plan" } \\
\text { [31-35] }\end{array}$ & $\begin{array}{l}\text { Supporting the public in recycling and re-using } \\
\text { waste/raising public awareness of landfills and changing } \\
\text { consumer behaviour }\end{array}$ \\
\hline Tokyo & "Zero waste city" [36] & $\begin{array}{l}\text { This concept is practiced in Japanese enterprises and } \\
\text { extended from enterprises to cities through policies }\end{array}$ \\
\hline America & “Zero landfill” [37] & “Zero landfill” of fabric waste will be realized in 2037. \\
\hline China & $\begin{array}{l}\text { Waste Import Requirements } \\
\qquad[38,39]\end{array}$ & $\begin{array}{l}\text { It has clearly been stipulated that waste such as waste } \\
\text { textile materials shall be prohibited from entering China. }\end{array}$ \\
\hline Korea & Green Growth Act & $\begin{array}{c}\text { Businesses should gradually adopt an environmental } \\
\text { management system (EMS) }\end{array}$ \\
\hline
\end{tabular}

According to Table 3, it can be concluded that the laws and regulations of the abovementioned governments on waste-clothing recycling have explicit provisions. The regulations that apply to waste management are also valid for clothing. The policy not only increases the life of waste clothing, but also achieves the maximum utilization of energy and 
the maximum saving of carbon emissions. The requirements of environmental responsibility and circular economy should be fully respected. It can be seen that the promulgation of the policy has prompted the whole textile and garment industry towards a clear direction in recycling, while improving consumers' awareness of recycling.

\subsection{Classification of Waste-Clothing Recycling}

The diversification of waste-clothing recycling methods makes waste-clothing recycling a growth point of sustainable development in the textile and clothing industry. However, the classification of waste clothing is also a key link in the recycling process. According to the existing literature, waste clothing classification includes: the degree of damage, dirtiness, production value, material value, color, product category, and inventory (see Table 4).

Table 4. Waste clothing classification cases and their influence.

\begin{tabular}{|c|c|c|}
\hline Category & Case & Influence \\
\hline \multirow{2}{*}{$\begin{array}{l}\text { Damage } \\
\text { degree }\end{array}$} & $\begin{array}{l}\text { In the condition of avoiding second pollution, waste } \\
\text { garments as raw material can be utilized on road-bed } \\
\text { construction, car textile, carpet and curtain, as well as } \\
\text { home textiles [40]. }\end{array}$ & $\begin{array}{l}\text { Improved the utilization rate of } \\
\text { waste clothing and extended the } \\
\text { life cycle. }\end{array}$ \\
\hline & $\begin{array}{l}\text { Waste clothes that are badly damaged and have no } \\
\text { value can be used for landfill or incineration [41]. }\end{array}$ & $\begin{array}{l}\text { Landfill occupies land resources, } \\
\text { incineration can generate } \\
\text { electricity, but produce pollution. }\end{array}$ \\
\hline $\begin{array}{l}\text { The degree } \\
\text { of dirtyness }\end{array}$ & $\begin{array}{l}\text { Waste clothing is divided into more than } 160 \\
\text { categories, static classifying area is set up, and } \\
\text { manually classified [42]. }\end{array}$ & $\begin{array}{l}\text { Transfer to other production as } \\
\text { another raw material. }\end{array}$ \\
\hline $\begin{array}{l}\text { Value of } \\
\text { manufacture }\end{array}$ & $\begin{array}{c}\text { Breakfast at Tiffany's is Audrey Hepburn's first } \\
\text { well-known work. Her gown was designed by famous } \\
\text { fashion designer Givenchy, the estimated value was } \\
\$ 800 \text { 000. It was later collected by the museum because } \\
\text { of its special value [7] }\end{array}$ & $\begin{array}{l}\text { Add value to products, especially } \\
\text { in the fashion and luxury sectors. }\end{array}$ \\
\hline \multirow[t]{2}{*}{$\begin{array}{l}\text { Value of } \\
\text { material }\end{array}$} & $\begin{array}{c}\text { Based on near infrared spectrum analysis, deep } \\
\text { learning theory was used to classify the waste textiles } \\
\text { qualitatively, realizing the automatic classification of } \\
\text { several common textiles, such as cotton and } \\
\text { polyester [43]. }\end{array}$ & $\begin{array}{l}\text { Accurate and reliable } \\
\text { classification, saving the } \\
\text { consumption of manual sorting. }\end{array}$ \\
\hline & $\begin{array}{l}\text { Design method of sensor and component classification } \\
\text { of automatic waste textile sorting machine [44] }\end{array}$ & $\begin{array}{l}\text { Waste clothing fabrics and } \\
\text { accessories are accurately sorted. }\end{array}$ \\
\hline Colour & $\begin{array}{c}\text { A real time and completely automated colour } \\
\text { classification tool for woolen clothes to be recycled has } \\
\text { been proposed. The tool uses the combination of a } \\
\text { matrix approach and an artificial neural network } \\
\text { approach to accurately recycle clothing of different } \\
\text { colors [45]. }\end{array}$ & No dyeing cost. \\
\hline $\begin{array}{l}\text { Production } \\
\text { categories }\end{array}$ & $\begin{array}{l}\text { The second-hand Harley Davidson jackets are sent to } \\
\text { Japan, second-hand ties to Vietnam, second-hand } \\
\text { raincoats to London, and jeans around the world [40]. }\end{array}$ & $\begin{array}{l}\text { Establish professional recycling } \\
\text { sales channels to maximize } \\
\text { product profits. }\end{array}$ \\
\hline Overstock & $\begin{array}{c}\text { Average brands usually contact the professional } \\
\text { managers of second-hand recycling to transfer } \\
\text { overstocked goods into the secondary market through } \\
\text { the middleman [40] }\end{array}$ & $\begin{array}{l}\text { Solve the limited industrial } \\
\text { resources and improve the } \\
\text { development of new products. }\end{array}$ \\
\hline
\end{tabular}

\subsection{Treatment of Waste-Clothing Recycling}

Waste clothes can be classified by various methods and then processed separately, according to the purpose of reuse. According to the existing literature, the treatment of waste-clothing recycling can be summarized as secondary use and regeneration use. 


\subsubsection{Secondary Use}

Secondary use refers to the simple sterilization and cleaning of clothes after recycling for direct reuse [46]. The secondary uses of waste clothes include qualitative utilization, export, and donation.

Classification technology is very important in the quality utilization of recycling treatment. Accordingly, researchers have studied the recycling and classification of clothing. For example, Bukhari et al. explained the relevant practices of clothing recycling in France. The collected waste clothes were put into containers, classified as collected waste clothes, and delivered to charity organizations for sale, donation, and export [27]. Since waste clothing is often composed of multi-component fibres, in order to effectively achieve the purpose of recycling, researchers separated the clothing fabric composed of multiple fibres into a single component. For instance, Navone et al. used the enzymatic separation of wool fibre and polyester in the fabric. Enzymatic treatment destroys the wool fibres in the fabric, and makes the remaining polyester fibres into polyester yarn, which is used in new products [47]. Li mentioned in his research that waste protective clothing was used as a raw material to make floor and wall bricks. Recycled plastics from clothing can also be incorporated into concrete as fine aggregate (12.5\% by weight) [15]. Roushan et al. studied the use of recycled cotton/polyester fibres in clothing as raw materials, and used the chemical bonding method to develop heat insulation and sound insulation samples for the construction industry by combining recycled waste cotton fibres and recycled PET fibres [48].

In terms of the waste clothing export, data from the International Trade Commission shows that from 1989 to 2003, the export of waste clothing from the United States increased twice, reaching nearly 7 billion pounds per year, and waste clothing exported from the United States was sold in more than 100 countries [16]. Based on environmental responsibility and circular economy considerations, some countries have banned recycled clothing from entering the country, keeping the local textile industry internationally competitive; for example, China, a major destination for solid-waste recycling and disposal in the global circular economy, has banned 24 types of solid waste from entering the country, including waste textile materials [49]. Waste-clothes recycling faces challenges due to the policy of banning the import of waste clothes [27].

As for the donation of waste clothing, some countries and clothing brands take action to donate waste clothes. For example, communities in many Chinese cities have set up recycling bins for waste clothes to recycle unused clothing from residents and endow them to public welfare organizations, thus realizing secondary use. American citizens donated waste clothing to charities and received corresponding tax incentives from the government, and charities cleaned the waste clothing and textiles and donated them to the Salvation Army and Goodwill Industries [16]. The Uniqlo sorted and disinfected $80 \sim 90 \%$ of the recycled clothing, and donated them to refugees through UNHCR and Japan Relief Clothing Center [19,20]. PACLANTICK launched the "Clothing acting, mind moving" activity of children's wear recycling and donation, which extends the usage value of garments, but also motivates consumers to integrate into the industry [40].

\subsubsection{Regeneration Use}

Regeneration use refers to the treatment of waste clothing through certain methods to create new products, and apply them to new fields. New raw materials or products can be obtained by separating or re-weaving waste-clothing fabrics using relevant technologies. The principle of these technologies can be roughly classified as chemical treatment and physical treatment.

Through the literature analysis on the recycling and treatment methods of waste clothing, it can be seen that chemical methods are widely used in the recycling and treatment of waste clothes. Smits et al., for instance, refer to studies on the chemical recovery of cellulose, polyester and mixed materials [50]. Sakthivel et al. used rag-tearing technology to transform pre-consumption cotton textile waste and defective fabric into fibre form. The 
fibrous web of shoddy was produced using the carding machine. This web was used for developing thermoset composites as a reinforcement material [51]. As synthetic fibres cannot be eliminated, Popescu et al. proposed a sustainable and cleaner microwave (MW)-assisted process of dyeing acrylic knitted fabrics with natural dyes, based on curcumin extracted from turmeric powder (TP) [52]. Haslinger et al. proposed a method to separate cotton and polyester, a superbase-based ionic liquid, which allows the selective dissolution of the cellulose component, and increases the probability of reuse of cotton-polyester-blended waste clothing [53]. Patricia et al. studied polyester concrete using waste cotton fibre as a raw material, and gamma irradiated it. Their test results showed that the compressive strength and flexural strength of composite concrete with waste cotton fibre were improved [54].

The chemical method is mainly used to achieve the purpose of waste-clothing recycling by separating the fibre composition, whereas the physical method is mainly used to improve the lifecycle of waste clothing by cutting the recycled clothing. Different scholars also launched studies in the physical methods section; for example, Norris et al. mention a variety of recycling and transformation schemes for used clothing. Some schemes include the retrofitting of shirts to be sold to others as skirts, worn silk garments being decorated and designed for resale, etc. [55]. Russell et al. described the physical recovery method of natural wool fibre. There are two kinds of recovery of wool fibre. Firstly, wool fibre waste before consumption includes fibres, yarns and other waste products from the production process. This recovery method minimizes fibre breakage and increases residual fibre length after a mechanical pulling process. Secondly, wool waste after consumption includes clothing discarded by users due to wear and tear; the recycled wool textile is cut down and added to the wool-reprocessing process [56,57]. Luiken et al. discussed the importance of design for recycling (D4R) in denim, the options for upcycling denim waste and the possibility of producing denim from other waste materials [58].

Sustainable design is also one of the physical considerations in the technology of wasteclothing recycling. Different scholars on the related research on the sustainable design include Gwilt et al., who expounded the fashionable material upgrade where fashion designers can design a sustainable method in second-hand clothing, using a redesigned pattern to tailor new garments [21]. Gam et al. discussed the application of design and disassembly methods in the design of men's jackets, so that men's jackets can be easily disassembled and recycled at the end of their lifecycle [59]. Janigo et al. studied the conversion of textile waste into raw materials for new fashion clothing [60]. Various brands have also taken corresponding actions in the recycling and reuse of waste clothes. Maison Briz Vegas uses waste clothes for fashion production, and their process and production methods practice sustainable development actions [61-63]. Table 5 shows the re-design projects of waste clothing carried out by Brazilian brands and designers in the field of fashion. These projects increase the value of waste clothing and fabrics [62-64]. These achievements help to improve the quality of life of the public, and bring economic benefits (see Table 5).

Table 5. Cases of waste clothing reuse by brands/designers.

\begin{tabular}{cc}
\hline Brand/Designer & Project/Action \\
\hline Retail Fashion & $\begin{array}{l}\text { The project is already the result of cooperation between the textile industry } \\
\text { and the government, with the participating garment enterprises producing } \\
\text { approximately 12 tons of textile waste per day. The project aims to manage } \\
\text { the commercialization of textile waste, promote its reuse as a raw material, } \\
\text { and develop a waste management plan in accordance with the national } \\
\text { solid waste policy [65-67]. }\end{array}$ \\
$\begin{array}{c}\text { The Brandili } \\
\text { Textile Brand }\end{array}$ & $\begin{array}{c}\text { Based on China's strategy for the sustainable development of natural } \\
\text { resources, the company reuses textile waste by cooperating with raw } \\
\text { material factories that provide ecological yarn production (from textile } \\
\text { materials to plastic bottles) [62]. }\end{array}$ \\
\hline
\end{tabular}


Table 5. Cont.

\begin{tabular}{cc}
\hline Brand/Designer & Project/Action \\
\hline $\begin{array}{c}\text { The Insecta } \\
\text { Shoes Brand }\end{array}$ & $\begin{array}{c}\text { The brand's products are made from used clothing, fabric waste and } \\
\text { recycled PET, some of which are purchased on the second-hand market or } \\
\text { supplied by the Sao Paulo Reusable Fabric Bank [68,69]. }\end{array}$ \\
\hline $\begin{array}{c}\text { The Ecosimple } \\
\text { Brand }\end{array}$ & $\begin{array}{c}\text { All products of this brand are made from 100\% recycled materials, using } \\
\text { materials recovered from clothing or fabric waste discarded by plastic } \\
\text { bottle garment factories and waste from the spinning process [62,70]. }\end{array}$ \\
\hline
\end{tabular}

\section{Literature Collection and Descriptive Analysis}

Based on the summary of waste-clothing-related literatures, this paper focuses on the analysis of waste-clothes recycling mode classification, and the recycling technology development status. Due to the fact that Citespace software can only analyze articles in the WOS Core Database, we included other articles related to waste clothing for the analysis. Citespace software was used for cluster analysis of these two parts of the literature, and the publication year and key word atlas of sustainable waste-clothing recycling and reuse articles were analyzed. Moreover, the new trends of waste-clothing recycling and reuse were also described and analyzed.

\subsection{Literature Collection}

First of all, the authors defined appropriate research topics and then retrieved articles from the WOS Core Database. The literature from the WOS Core Database in Chapter 2 was screened out. The relevant publications include journal articles, book chapters and conference papers, which were screened in this database to form large literature data. This process has helped to form a structured, detailed and effective literature review and can provide valuable suggestions for future review writing.

The literatures were queried using Boolean operators and keyword search structured search strings. Keywords were selected based on their relevance to the topic of wasteclothing recycling and words that were most commonly used in research articles and by researchers. We used the following search strings:

[clothing OR garment OR apparel] AND [waste OR reuse OR recycling] AND [global OR Europe OR France OR Brazil OR China] AND [mode OR classification OR category] AND [law OR legislation OR strategy OR firm OR enterprise OR Internet] AND [social value OR market value].

Our retrieval then found that different scholars in the clothing field have previously carried out the review of related research; for example, Sandin et al. used the following search string: [life cycle assessment and life cycle analysis or LCA (environmental or energy) and (assessment or evaluation or analysis) and (textile clothing or fashion or clothing) and (recycling or reuse or collaborative consumption or two hand or stock or share or rent) [71]. Sandin's review used LCA terms to elaborate on the environmental impact of textile recycling, expanding the terms related to reuse and recycling. Wagner et al. reviewed the current situation of recycled textiles and recycled clothing and proposed actions and specific suggestions from the perspectives of consumers, manufacturers, brands and designers [7].

Subsequently, the author assessed the literature that was found. After a repeated and thorough literature review, in order to form a detailed and accurate literature review, we excluded the research literature with the same data and similar problems, having the same author repeated in various research articles. We also excluded literature that did not involve waste clothing, and excluded articles with consistent but incoherent central themes. Table 6 summarizes the conditions for inclusion and exclusion of the literatures. 
Table 6. Inclusion and exclusion criteria for systematic literature review, adapted from Wagner [7].

\begin{tabular}{cc}
\hline Inclusion Criteria & Exclusion Criteria \\
\hline WOS Core Database from index to 2021 article & $\begin{array}{c}\text { Unable to search full text, } \\
\text { repeated research articles and } \\
\text { incoherent articles }\end{array}$ \\
\hline $\begin{array}{c}\text { [clothing] AND [waste OR reuse OR recycling] AND [global } \\
\text { OR Europe OR America OR Brazil OR China] AND [model } \\
\text { OR classification] AND [law OR strategy OR enterprise OR } \\
\text { Internet] AND [social value OR market value] }\end{array}$ & $\begin{array}{c}\text { Literatures not directly related } \\
\text { to waste-clothing recycling }\end{array}$ \\
\hline
\end{tabular}

Finally, 172 literatures were generated in WOS Core Database by retrieving strings. According to the inclusion and exclusion conditions, unqualified articles were excluded. On this basis, literature belonging to WOS Core Database in Chapter 2 was added. Therefore, the total number of research samples included in the recycling of waste clothing was 231.

\subsection{Description and Analysis of Article Trends and Research Topics}

\subsubsection{Trend Analysis of Articles}

See Figure 1 for the trend of literatures related to waste-clothing recycling screened by WOS Core Database. The time span was 1992-2021, and the retrieval deadline was 5 April 2021. The search type was waste-clothing recycling, the literature type was articles, and the retrieval topic was waste-clothing recycling.

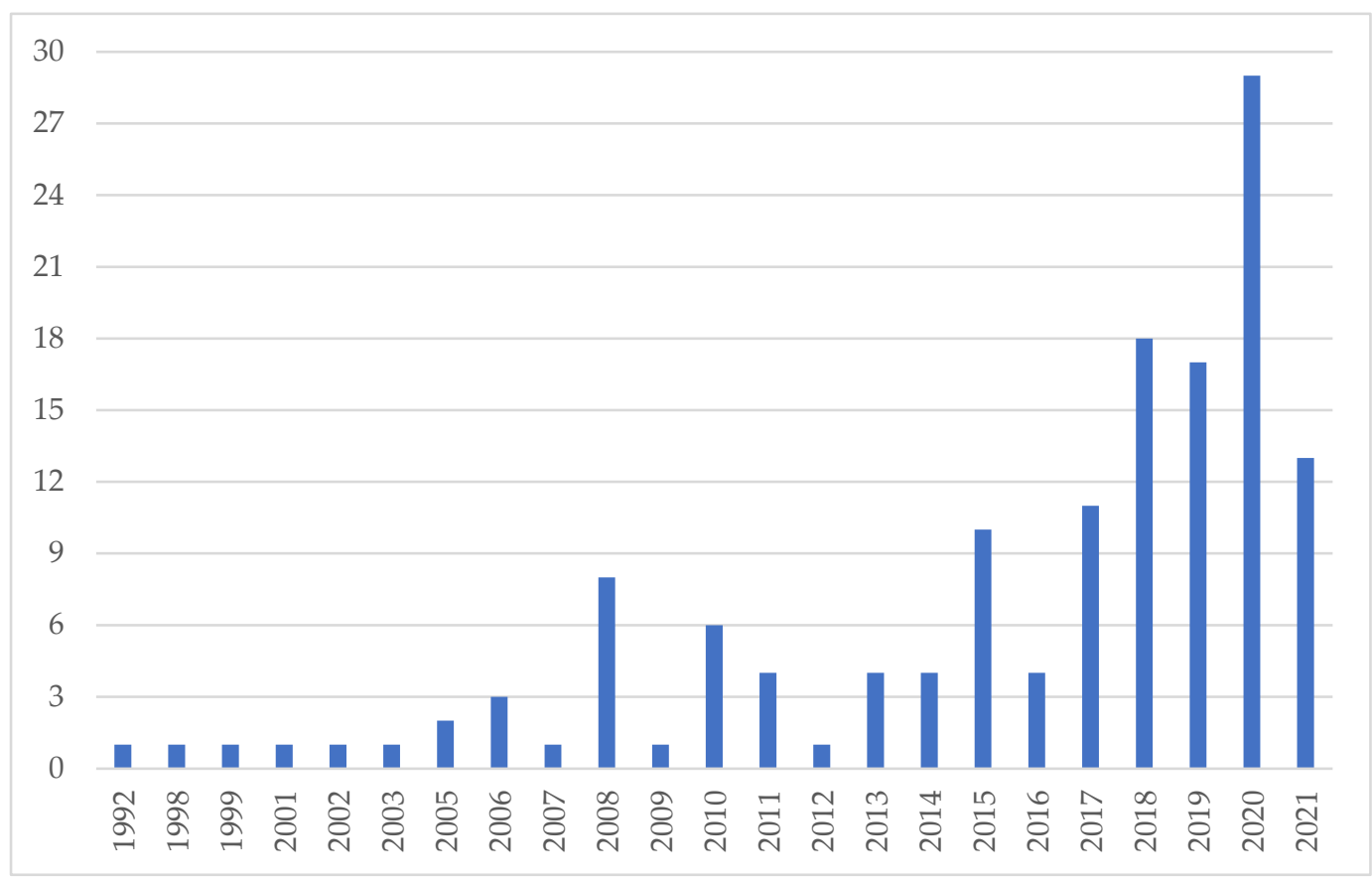

Figure 1. Distribution of the publication of 231 papers on waste-clothing recycling and reuse by publishing year.

The first literature related to the research on waste-clothing recycling collected by WOS core database was published in 1992. The number of articles published after 1992 and 2007 was relatively small, indicating that between 1992 and 2007 people had little awareness of waste-clothing recycling and only a few people realized the importance of waste-clothing recycling. In 2008, compared with the previous years, the number of articles on the waste-clothing recycling increased from 1-3 to 8. In 2008, the European Union introduced the European Waste Ordinance. Although this only came into effect in 2010, this indicates that in 2008, people's awareness of waste-clothing recycling increased compared with before this date. The research field of waste-clothing recycling has received more and 
more attention, and the concepts of environmental responsibility and circular economy have received more attention in the political field and industry since 2008 [71]. From 2010 to 2014 , the number of papers on waste-clothing recycling and reusing decreased, compared with 2008, indicating that researchers paid less attention to waste-clothing recycling and reuse during this period; however, some scholars still paid attention to and conducted research. Influenced by environmental responsibility and circular economy, the number of articles published between 2015 and 2019 showed a fluctuating upward trend, with an average of 14 articles published every year. It can be seen that researchers paid more attention to waste-clothing recycling and reuse in this period. In 2020, the number of articles published on waste-clothing recycling and reuse increased significantly, reaching 29 , indicating that there were many researchers in this field by 2020 . This shows that people's attention to waste-clothing recycling and reuse has greatly increased.

\subsubsection{Research Topic Trends}

In the WOS Core Database, the most cited papers were research papers, in addition to the first paper and the third paper which were book articles, and the second paper, which was a review of "the latest research on the sources of harmful compounds discharged from solid waste landfill review of the US experience." Excluding the above three papers, a paper by Nelles, M, J. et al. on the development of waste management towards sustainable circular economy in Germany was cited the most (see Table 7).

Table 7. Reltaed publications and their citation situation.

\begin{tabular}{|c|c|c|c|c|}
\hline Grade & Title & Author/Year & Journal & Cite \\
\hline 1 & $\begin{array}{l}\text { Shaping sustainable fashion: changing the } \\
\text { way we make and use clothes. }\end{array}$ & $\begin{array}{c}\text { A Gwilt, } \mathrm{T} \\
\text { Rissanen } 2012\end{array}$ & Books & 211 \\
\hline 2 & $\begin{array}{l}\text { A review of recent studies on the sources of } \\
\text { hazardous compounds emitted from solid } \\
\text { waste landfills: a US experience. }\end{array}$ & Reinhart, D.R. 1993 & $\begin{array}{l}\text { Waste } \\
\text { Management \& } \\
\text { Research }\end{array}$ & 111 \\
\hline 3 & $\begin{array}{c}\text { Recycling Indian clothing: global contexts } \\
\text { of reuse and value. }\end{array}$ & Norris, L. 2010 & Books & 103 \\
\hline 4 & $\begin{array}{c}\text { Waste management in } \\
\text { Germany-development to a sustainable } \\
\text { circular economy? }\end{array}$ & $\begin{array}{c}\text { Nelles, M., J. } \\
\text { Gruenes, and G. } \\
\text { Morscheck, } 2016\end{array}$ & $\begin{array}{l}\text { Procedia } \\
\text { Environmental } \\
\text { Sciences }\end{array}$ & 95 \\
\hline 5 & $\begin{array}{l}\text { Consumer textile recycling as a means of } \\
\text { solid waste reduction. }\end{array}$ & $\begin{array}{c}\text { Koch, K., T.J.F. } \\
\text { Domina, and C.S.R. } \\
1999\end{array}$ & $\begin{array}{l}\text { Family \&consumer } \\
\text { sciences }\end{array}$ & 93 \\
\hline 6 & $\begin{array}{l}\text { UK waste minimisation clubs: a } \\
\text { contribution to sustainable waste } \\
\text { management. }\end{array}$ & $\begin{array}{l}\text { Phillips, P.S., et al. } \\
1999\end{array}$ & $\begin{array}{l}\text { Resources, } \\
\text { Conservation and } \\
\text { Recycling }\end{array}$ & 86 \\
\hline 7 & $\begin{array}{l}\text { A carbon footprint of textile recycling: a } \\
\text { case study in Sweden. }\end{array}$ & $\begin{array}{l}\text { Zamani, B., et al. } \\
2015\end{array}$ & $\begin{array}{c}\text { Journal of } \\
\text { industrial ecology }\end{array}$ & 81 \\
\hline 8 & $\begin{array}{l}\text { An environmental perspective on clothing } \\
\text { consumption: consumer segments and their } \\
\text { behavioral patterns. }\end{array}$ & $\begin{array}{l}\text { Gwozdz, W., K.S. } \\
\text { Nielsen, and T. } \\
\text { Mueller, } 2017\end{array}$ & Sustainability & 79 \\
\hline 9 & $\begin{array}{c}\text { A review of the socio-economic advantages } \\
\text { of textile recycling. Journal of } \\
\text { cleaner production. }\end{array}$ & $\begin{array}{l}\text { Leal Filho, W., } \\
\text { et al., } 2019\end{array}$ & $\begin{array}{l}\text { Journal of Cleaner } \\
\text { Production }\end{array}$ & 68 \\
\hline 10 & $\begin{array}{l}\text { Challenges facing the sustainable } \\
\text { consumption and waste management } \\
\text { agendas: perspectives on UK households. }\end{array}$ & $\begin{array}{l}\text { Tudor, T., et al., } \\
2011\end{array}$ & Local Environment & 59 \\
\hline
\end{tabular}

The research methods used in this paper are mainly quantitative methods, such as questionnaires, expert interviews, etc. In addition, some literature also used experimental research methods, for example, life-cycle assessments, test experiments $[43,51]$, sensory experiments, decomposition methods [47], chemical bonding methods, etc. In order to better study waste-clothing reuse, various cases appear in some articles [72-76] to support the feasibility of the theory. Multiple theories are used in the review, such as technology-use 
theory, source credibility theory, [77] and pollution theory [19,41]. In addition, existing papers have also studied a variety of treatment technologies for recycling, for instance, incineration technology [48] and intelligent recovery technology [42,64].

Regarding the map of clustering centrality keywords in Figure 2, the red font is the cluster name; it can be seen that the largest cluster is "management", and the cluster of this word is dark green. Therefore, it can be seen that the key research topic in the field of waste-clothing recycling is management. According to the time slice, the average publication year of "management" was 2014, which also shows that after 2014, due to changes in the environment, human began to pay more attention to waste management, including the management strategy of waste clothing. "Reuse" is the cluster associated with "management". In recent years, an increasing number of researchers have begun to pay attention to waste management and reuse. The map also indicates that the management and reuse of waste clothing will likely be a key cluster for future research. The second largest cluster was "temperature"; according to the time slice analysis, the average publication year of this keyword was 2016, indicating that the keyword trend of many articles published by scholars in 2016 was "temperature". Figure 2 shows that the keyword trend is closely related to biodegradation and green synthesis, indicating that researchers paid attention to degradation and waste clothing reuse in 2016. "Reuse" ranked third in the cluster, with an average year of 2013. This type of evidence indicates that waste-clothing recycling has become a research hotspot since 2013. "Textile" occupies the fourth place in the cluster, with an average year of 2017, which shows that the research trend of scholars in 2017 regarded the sustainable research of textiles.

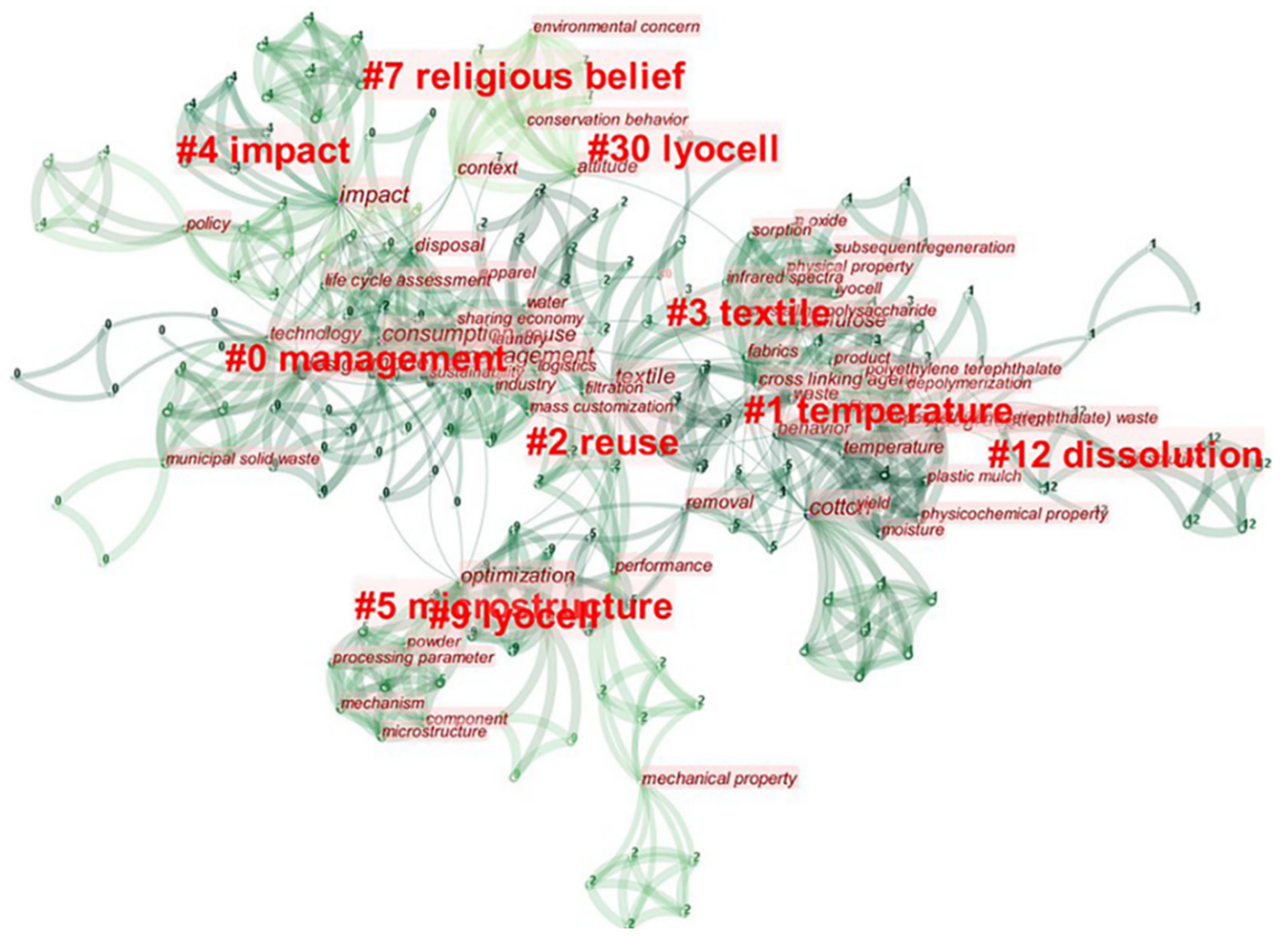

Figure 2. Keywords clustering atlas of 231 references.

\section{Results Analysis and Discussion}

In this section, the 231 articles previously discussed are qualitatively analyzed for waste-clothes recycling processing technology, as well as social value and market value, 
based on the literature. From the perspective of environmental responsibility and circular economy, we assessed the research's understanding of the sustainability of waste-clothes recycling. Processing technology and its social value and market value are discussed in the analysis.

Sustainability awareness is very important; it is the basis of waste-clothing recycling. This can include the processing of technical renovations and upgrades, the creation of sustainable raw materials or products applied to the new field, and the making of the textiles. Thus, the market value and social value of the clothing sector has been improved and enhanced.

\subsection{Sustainability Awareness of Waste-Clothing Recycling}

The sustainability awareness of different social roles is an important field in sustainability research. Sustainable development is oriented to different industries and is, to a large extent, guided by consumer consciousness; thus, awareness of sustainability is the primary consideration in the study of sustainable development. According to existing literatures, this section discusses the sustainability awareness of waste-clothing recycling including: the understanding of producers and governments on the sustainability of clothing; consumers' disposal of waste clothing; the social value and market value brought by the behavior of producers and government consumers.

\subsubsection{The Social Value of Waste-Clothing Recycling}

In this paper, the recycling mode, recycling technology, and classification management of waste-clothing recycling are studied. The results show that policy plays a crucial role in waste-clothing recycling. For example, due to the implementation of EPR policy, the collection rate and recovery rate of post-consumption textiles increased by three times, and the policy of banning the import of waste clothing in African countries effectively developed the local textile industry [27]. Guidance in policy can effectively promote waste-clothing recycling by producers, and enable consumers to accept reused products.

Under the guidance of policies, producers also take corresponding actions to recycle clothing, such as setting up a recycling system, using fibres or yarns of recyclable ingredients in new products, extracting raw materials from waste clothing as the input of the next product, and other measures. Research shows that the reuse of waste-clothing recycling lies in effective management. The value chain collaboration of sustainable development management, knowledge sharing, and the marketization of waste-clothing recycling are all actions that producers must take to successfully practice circular economy [78]. An increasing number of enterprises have realised the importance of waste-clothes recycling management, and have proposed a retailer's recycling plan [79]. The producers' consciousness of environmental protection is a great progress in waste-clothing reuse, reducing the textile and apparel industry's consumption of carbon, and saving energy to create new products. Other producers utilise retail strategies and promotion strategies, not only to promote their own marketing [80], but also because the life cycle of waste-clothing recycling must increase with sustainable design [81], in order to achieve the zero-waste goal [82]. Such measures also drive consumers to actively participate in waste-clothing recycling and reuse.

Under the guidance of these producers, consumers have reached a new understanding of waste-clothing recycling, and have taken action. Consumers have taken the network platform as a new channel for the disposal of waste clothes, and consequently the disposal behavior of waste clothes has greatly improved [83]. Consumers can effectively recycle waste clothes through multiple specific recycling modes, which promotes the classification and management of waste clothes [84]. Research shows that the personal emotional value of products has the greatest influence on consumers with regard to waste-clothing recycling, whereas economic risk and performance risk do not affect consumers' attitude towards products [80]. There are significant differences between consumers in the use and disposal of clothing, and more measures to improve sustainability awareness are needed to alert 
consumers to the better choice of waste-clothing recycling, and the necessity of clothing reuse [84].

\subsubsection{Market Value of Waste-Clothing Recycling}

Governments have issued waste-clothing recycling policies, supporting the producers of waste-clothes recycling, in order to better protect the environment and reduce waste clothing's impact on the environment; the government has established a "textile industry linear economy to circular economy" [82]. The policy showed great potential, identifying new markets, and improving the situation of the textile waste-disposal industry [85].

The study found that many retailers also participate in recycling programs and are willing to exchange gift certificates for recycled clothing. Relevant studies have identified two major ways in which retailers currently assume post-retail responsibilities, including second-hand retail and product-recycling programs [86]. Recycling is the most important way to promote sustainability and circular economy to consumers. In addition, manufacturers add recyclable fibre into the clothing, which helps meet consumers' demand for clothing containing recyclable fibre. Thus, an increasing number of brands are willing to launch products containing recyclable fibre. Brands seeking to promote the concept of sustainability have removed toxic chemicals from their supply chains, a definite step towards a circular economy. Fabric banks extend the life-cycle of waste clothing or textile waste for new uses, and in the process, used clothing can also be resold to increase market value and achieve reuse.

The measures and actions taken by the government and retailers for waste-clothing recycling and reuse have promoted waste-clothing recycling and management, increased the utilization rate of waste clothing, improved its life cycle, and reduced the impact of textile and clothing waste on the environment.

\subsection{Processing Technology for Waste-Clothing Recycling and Reuse}

Social and market values are not only affected by sustainability awareness, but are also affected by waste-clothing disposal technology, and the sustainability of social and market values. Different processing techniques have different values, and sustainable waste-clothing processing technology is considered to be effective in this study. According to the existing literature, waste clothing is processed by physical technology and chemical technology to get new raw materials and products, in order to create new products and apply them in new fields.

\subsubsection{Physical Technology of Waste Clothing}

Physical technology regards waste clothing repair and redesign $[55,87,88]$. Used garments that cannot be repaired and reused are used as textile materials for other industries [89]. The wool textile part of the waste wool clothing is cut down and added into the wool-reprocessing process [57]. Used denim clothes with large degrees of wear are torn and reused [58].

As a result of physical technology, waste clothing produces different levels of waste, because the garments are redesigned and limited by the size of each available part of the second-hand clothing. Material costs account for a large proportion in clothing production, so the process of reuse to maximize the use of fabric can reduce unnecessary material loss and unusable waste clothing. This maximizes the use of fabrics to save on manufacturing costs and reduces the amount of fabric waste sent directly to landfill.

\subsubsection{Chemical Technology of Waste Clothing}

Polyester fibres from waste clothing are separated by spinning and enzymatic hydrolysis [90,91]. Recycled cotton and polyester fibres are chemically bonded to make double-layer non-woven fabric, which is then used in the building industry for heat and sound insulation [92,93]. The waste clothing containing cotton, polyester and acrylic fibre can be applied to new products through chemical treatment after adding biochar, and can 
prepare the textile material with an odor masking function with high thermal physiological comfort [94].

The development of recycling technology promotes waste clothing's sustainable disposal. The current recycling method of waste clothing is more beneficial to the environment and society than incineration, which is sufficient to prove that the reuse of waste-clothing recycling is reasonable. However, waste clothing still needs technological innovation to promote its upgrade cycle, and reused post-consumer materials to produce new products. The most effective way to improve the collection and disposal of post-consumption textiles is to implement environmental protection policies.

\subsection{Discussion Is Based on Environmental Responsibility and Circular Economy}

Due to the development trend of environmental responsibility and circular economy, many garment practitioners and government departments have realized the necessity of sustainability and provided corresponding measures and programs. In this section, the author discusses the advantages and disadvantages of recycling technology in order to understand the defects of waste-clothing recycling to the social value and market value, from the perspective of environmental responsibility and circular economy.

\subsubsection{Advantages and Disadvantages of Waste-Clothing Recycling Technology}

Research shows that the intelligent recycling system of waste clothing formed by internet and data analysis can effectively classify and manage waste clothing and allocate resources for reuse [95]. In addition, automatic sorting can improve the production process, production efficiency, and the number of recycled textiles. Nevertheless, the recycling technology of waste clothing has technical limitations, such as the lack of fine classification of textile waste. Moreover, most existing methods cannot separate dyes and other pollutants from raw fibres [96].

The process of redesigning used clothing using physical techniques can result in much higher waste, due to the limitations of the original shape of the clothing being dismantled for use. We question how we can minimize the waste and carbon emission of the whole process, in addition of how to make the best use of disassembled parts and sewing thread and other waste. If a solution to the above problems is proposed, can the solution be universally applicable in the closed-loop supply chain environment? Does the optimized solution benefit the enterprise practice? How can we make it work in practice to benefit all participants in the industry? Researchers, policy makers and practitioners need to think deeply in order to explore these issues.

\subsubsection{Deficiency Social Value of Waste-Clothing Recycling}

Waste-clothing recycling lacks a comprehensive and coordinated framework and policy to improve the overall efficiency of the waste-clothing recycling ecosystem, and the lack of this framework has a negative impact on the ecosystem [97]. The independent work of different components of the waste-clothing recycling value chain causes a conflict of interest [98], and the lack of unified and generally accepted standards in the recycling industry affects its operation and development. If the operations of these processes are centralized, policies and regulations can be developed for specific industry standards, technical standards, classification standards and testing standards.

Due to the lack of various standards in a particular industry, a unified work within the industry cannot be formed. Thus, we must consider what insights the industry players can provide to form a uniform standard, and how unified classification management according to the composition of waste-clothing materials can be formed. All participating departments of waste-clothing recycling should conduct a unified operation, optimize management, and integrate resources and the transportation of waste clothing to the nearest recycling facility. They should also consider how they can reduce transportation distance and other transaction costs, and improve environmental protection and resource efficiency. 


\subsubsection{Deficiency Market Value of Waste-Clothing Recycling}

There is a correlation between the recycling of waste clothing and the public's attitude towards recycling. The public's limited understanding of the advantages of recycling leads to low recovery rates, inefficient markets and the indifference of stakeholders to large-scale investment [99]. The successful implementation of the policy depends on the individual behavior of the public. If public behavior is indifferent to the policy, the waste recovery policy may be ineffective [100,101]. In addition, consumers' insufficient understanding of the recyclability of textile materials and the content of potentially dangerous ingredients in the materials has a negative impact on the demand for recycled textiles. Some knowledge barriers (not knowing what to recycle) and attitude barriers (not familiar with the concept of recycling) are the two basic obstacles for recycling [102]. At the present time, many countries have given priority to public waste recycling, such as glass, wood, paper, plastic, and metal [103]; consequently, textile recycling priority level and promotion is low. Ineffective information dissemination has a negative impact on government management; regulators could not collect enough data to formulate the appropriate policy management necessary for the downstream textile recycling industry.

Due to consumers' limited cognition of waste-clothing recycling and their distrust of some recycling agencies in the industry, the recycling rate of waste clothing is low; subsequently, investors are indifferent to the waste-clothing recycling industry. Faced with this problem, we should consider how to effectively publicize the relevant knowledge of waste-clothing recycling to increase consumers' awareness of recycling. In order for recycling institutions to improve waste clothing recovery and recycling, we should observe whether the government can cooperate with recycling enterprises to gain the trust of consumers. We ask questions, such as; how do recycling enterprises maintain transparency of waste clothing flow and reproduction? How can the government develop a mode or policy to continuously improve recycling, consumer awareness, and information sharing? Waste-clothing recycling needs more participants and practitioners to make joint efforts to realize the waste-clothing recycling, in order to improve social and market value.

\subsubsection{Deficiencies and Suggestions}

This paper focuses on case studies to summarize and analyze waste-clothing recycling and reuse. This transfer of research results from one context to another is not applicable, and no sustainability rule can be applied to research in any context.

This study gives an important overview of the existing literature on recycling modes, recycling technology, and the classification management of waste clothing, including a descriptive analysis of the research trend of the amount of papers published and the research topic. Visualization of a keywords clustering group through the network graph (see Figure 2) analyzes the future research trends of waste-clothing recycling management. With the precise management of waste-clothing recycling as a starting point, the textile and apparel industry of sustainable development and circulation practices can provide solutions, and help policy makers and practitioners involved in the waste-clothing recycling further.

\section{Conclusions}

In this paper, the recycling mode and classification management of waste-clothing recycling and reusing are studied. According to the existing literature, there are differences in the understanding and measures of the producers, governments, and consumers, regarding waste-clothing recycling. Some producers are deeply aware of the necessity of waste-clothing recycling, whereas consumers' recognition still needs to be improved. The results showed that consumers' recognition of waste-clothing recycling was affected by various factors, such as the obstacles of recycling knowledge and recycling channels. Compared with other successfully recycled materials, there is a certain research gap in waste-clothing recycling management. Based on the recognition and actions of producers, governments, and consumers, the changes and complexities of waste-clothing recycling and 
its reuse management classifications have been observed in different studies. It was found in this study that the establishment of policies had a great driving force for waste-clothing recycling, but due to consumers' weak cognition of policies, or lack of understanding, there were differences in the efficiency of waste-clothing recycling in different countries.

In future research, the classification management and recycling of clothing fabrics and accessories can be considered, including the waste zippers manufactured by various materials, the new trend of button recycling, and the refined classification of various waste clothing fabrics by innovative technological development.

Author Contributions: Conceptualization, X.X. and Y.H.; methodology Y.H.; software, X.X. and M.W.; validation, X.Z. and X.D.; formal analysis, X.X. and Y.H.; investigation, X.X. and Y.H.; data curation, X.X. and Y.H.; writing-original draftpreparation, X.X. and Y.H.; writing-review and editing, X.Z. and X.D.; supervision, X.Z. and X.D. All authors have read and agreed to the published version of the manuscript.

Funding: This research was funded by National Natural Science Foundation of China (Grant Number: 61906129), China Association for Science and Technology Youth Support Talent Project (Grant Number: 2021-298), Postdoctoral Research Foundation of China (Grant Number: 2019M661929), and the Postdoctoral Science Foundation of Jiangsu Province (Grant Number: 2019Z285).

Institutional Review Board Statement: The study was conducted according to the guidelines of the Declaration of Helsinki, and approved by the Institutional Review Board (or Ethics Committee) of Soochow University.

Informed Consent Statement: Informed consent was obtained from all subjects involved in the study.

Conflicts of Interest: The authors declare no conflict of interest.

\section{References}

1. WRAP. Why We Should Be Focusing on Clothing as Well as Plastics? Available online: https://wrap.org.uk/blog/2018/11/whywe-should-be-focusing-clothing-well-plastics (accessed on 10 August 2021).

2. How to Make the Clothing Sector Fit for a Net Zero World? Available online: https://wrap.org.uk/blog/2020/01/how-makeclothing-sector-fit-net-zero-world (accessed on 1 September 2021).

3. WRAP. Clothing. Available online: https://wrap.org.uk/resources/guide/textiles/clothing (accessed on 2 September 2021).

4. WRAP. Textiles. Available online: https://wrap.org.uk/resources/guide/textiles (accessed on 5 September 2021).

5. Watson, D.; Palm, D.; Brix, L.; Amstrup, M.; Syversen, F.; Nielsen, R. Exports of Nordic Used Textiles: Fate, Benefits and Impacts; Nordic Council of Ministers: Copenhagen, Denmark, 2016.

6. United Nations. Available online: https://www.un.org/en/actnow/facts-and-figures (accessed on 10 October 2021).

7. Wagner, M.M.; Heinzel, T. Human Perceptions of Recycled Textiles and Circular Fashion: A Systematic Literature Review. Sustainability 2020, 12, 10599. [CrossRef]

8. Filho, W.L.; Ellams, D.; Han, S.; Tyler, D.; Boiten, V.J.; Paço, A.; Moora, H.; Balogun, A.-L. A review of the socio-economic advantages of textile recycling. J. Clean. Prod. 2019, 218, 10-20. [CrossRef]

9. Sandin, G.; Peters, G.M. Environmental impact of textile reuse and recycling-A review. J. Clean. Prod. 2018, 184, 353-365. [CrossRef]

10. Hole, G.; Hole, A.S. Recycling as the way to greener production: A mini review. J. Clean. Prod. 2018, 212, 910-915. [CrossRef]

11. Rotimi, E.; Topple, C.; Hopkins, J. Towards A Conceptual Framework of Sustainable Practices of Post-consumer Textile Waste at Garment End of Lifecycle: A Systematic Literature Review Approach. Sustainability 2021, 13, 2965. [CrossRef]

12. Grębosz-Krawczyk, M.; Siuda, D. Attitudes of Young European Consumers Toward Recycling Campaigns of Textile Companies. Autex Res. J. 2019, 19, 394-399. [CrossRef]

13. Zhang, L.; Wu, T.; Liu, S.; Jiang, S.; Wu, H.; Yang, J. Consumers' clothing disposal behaviors in Nanjing, China. J. Clean. Prod. 2020, 276, 123184. [CrossRef]

14. Zhou, J.; Jiang, P.; Yang, J.; Liu, X. Designing a smart incentive-based recycling system for household recyclable waste. Waste Manag. 2021, 123, 142-153. [CrossRef]

15. Li, C.; Mak, S.L.; Tang, W.F.; Wu, M.Y.; Lam, S.K. Development of IoT-based Smart Recycling Machine to collect the wasted Non-woven Fabric Face Mask (NFM). In Proceedings of the 2020 IEEE International Symposium on Product Compliance Engineering-Asia (ISPCE-CN), Chongqing, China, 6-8 November 2020.

16. Claudio, L. Waste Couture: Environmental Impact of the Clothing Industry. Environ. Health Perspect. 2007, 115, A449-A454. [CrossRef]

17. Lascity, M.E.; Cairns, M.R. Complicated Green Advertising: Understanding the Promotion of Clothing Recycling Efforts. Westminst. Pap. Commun. Cult. 2020, 15, 44-62. [CrossRef] 
18. Watson, D.; Gylling, A.C.; Andersson, T.; Heikkilä, P. Textile-to-Textile Recycling: Ten Nordic Brands that Are Leading the Way; Nordic Council of Ministers: Copenhagen, Denmark, 2017.

19. Jäger, C. To Recycle, or not to Recycle? An Analysis of Consumption and Recycling Awareness of Consumers in Contemporary Japan, with a Focus on Uniqlo's All-Product Recycling Initiative. Bachelor's Thesis, Stockholm University, Stockholm, Sweden, 2019.

20. Chow, P.-S.; Li, C.K.Y. Towards Closed-Loop Fashion Supply Chains-Reflections from Retailer-Facilitated Used Apparel Collection Programs, in Contemporary Case Studies on Fashion Production, Marketing and Operations; Springer: Berlin/Heidelberg, Germany, 2018; pp. 219-239.

21. Gwilt, A.; Rissanen, T. Shaping Sustainable Fashion: Changing the Way We Make and Use Clothes; Routledge: London, UK, 2012.

22. Bishop, S.M. The professional clothing bank as evidence-based practice. J. Evid.-Inf. Soc. Work 2015, 12, 198-219. [CrossRef] [PubMed]

23. Scheibler, J. Circular Economy: Implications for the Swiss Fashion Retail Industry. Bachelor's Thesis, Zurich University of Applied Sciences, Winterthur, Switzerland, 2017.

24. Xiaojuan, Y.; Xiaolei, W. Status Quo of Reuse and Recycle of Clothes in China and Overseas. Shandong Text. Econ. 2013, 7, 11-13.

25. Gwozdz, W.; Müller, T.; Nielsen, K.S. An Environmental Perspective on Clothing Consumption: Consumer Segments and Their Behavioral Patterns. Sustainability 2017, 9, 762. [CrossRef]

26. Xu, C.-K.; Cheng, H.; Liao, Z.-J.; Hu, H. An account of the textile waste policy in China (1991-2017). J. Clean. Prod. 2019, 234, 1459-1470. [CrossRef]

27. Bukhari, M.A.; Carrasco-Gallego, R.; Ponce-Cueto, E. Developing a national programme for textiles and clothing recovery. Waste Manag. Res. 2018, 36, 321-331. [CrossRef]

28. Nelles, M.; Gruenes, J.; Morscheck, G. Waste management in Germany—Development to a sustainable circular economy? Procedia Environ. Sci. 2016, 35, 6-14. [CrossRef]

29. Wei-min, X.U. Study of the Institutional Characteristic and Implication of German Circular Economy. China Popul. Resour. Environ. $2007,5,1-12$.

30. Stokes, R.G.; Köster, R.; Sambrook, S.C. The Business of Waste: Great Britain and Germany, 1945 to the Present; Cambridge University Press: Cambridge, UK, 2013.

31. Wang, D.; Tang, Y.-T.; Long, G.; Higgitt, D.; He, J.; Robinson, D. Future improvements on performance of an EU landfill directive driven municipal solid waste management for a city in England. Waste Manag. 2020, 102, 452-463. [CrossRef] [PubMed]

32. Bennett, C. Landfill Gas-to-Energy in the US and UK: An Analysis of Differing Policy Objectives regarding Landfill Gas and Accompanying Regulations and Incentives. Georget. Environ. Law Rev. 2010, 23, 531.

33. Salemdeeb, R.; Al-Tabbaa, A.; Reynolds, C. The UK waste input-output table: Linking waste generation to the UK economy. Waste Manag. Res. 2016, 34, 1089-1094. [CrossRef]

34. Phillips, P.S.; Read, A.D.; Green, E.A.; Bates, M.P. UK waste minimisation clubs: A contribution to sustainable waste management. Resour. Conserv. Recycl. 1999, 27, 217-247. [CrossRef]

35. Tudor, T.; Robinson, G.M.; Riley, M.; Guilbert, S.; Barr, S.W. Challenges facing the sustainable consumption and waste management agendas: Perspectives on UK households. Local Environ. 2011, 16, 51-66. [CrossRef]

36. Fujita, K.; Hill, R.C. The zero waste city: Tokyo's quest for a sustainable environment. J. Comp. Policy Anal. 2007, 9, 405-425. [CrossRef]

37. Reinhart, D.R. A review of recent studies on the sources of hazardous compounds emitted from solid waste landfills: A US experience. Waste Manag. Res. 1993, 11, 257-268. [CrossRef]

38. Qu, S.; Guo, Y.; Ma, Z.; Chen, W.-Q.; Liu, J.; Liu, G.; Wang, Y.; Xu, M. Implications of China's foreign waste ban on the global circular economy. Resour. Conserv. Recycl. 2019, 144, 252-255. [CrossRef]

39. Sung, H.; Lee, J. Environmental Management Portfolio of Korean Fashion Brands. J. Glob. Fash. Mark. 2011, 2, 44-54. [CrossRef]

40. Wang, X.-L. The Study of Classifying Recycling of City Waste Textile and Garment. DEStech Trans. Eng. Technol. Res. 2017, 3, 35-38. [CrossRef]

41. Hollins, O. Recycling of Low Grade Clothing Waste. Defra Contract Reference: WRT152; Nonwovens Innovation \& Research Institute Ltd.: Leeds, UK, 2006.

42. Botticello, J. Between Classification, Objectification, and Perception: Processing Secondhand Clothing for Recycling and Reuse. Textile 2012, 10, 164-183. [CrossRef]

43. Liu, Z.; Li, W.; Wei, Z. Qualitative classification of waste textiles based on near infrared spectroscopy and the convolu-tional network. Text. Res. J. 2020, 90, 1057-1066. [CrossRef]

44. Riba, J.-R.; Cantero, R.; Canals, T.; Puig, R. Circular economy of post-consumer textile waste: Classification through infrared spectroscopy. J. Clean. Prod. 2020, 272, 123011. [CrossRef]

45. Furferi, R.; Governi, L. The recycling of wool clothes: An artificial neural network colour classification tool. Int. J. Adv. Manuf. Technol. 2008, 37, 722-731. [CrossRef]

46. Tripa, S.; Indrie, L. Households Textile Waste Management in the Context of a Circular Economy in Romania. Environ. Eng. Manag. J. 2021, 20, 81-87. [CrossRef]

47. Navone, L.; Moffitt, K.; Hansen, K.-A.; Blinco, J.; Payne, A.; Speight, R. Closing the textile loop: Enzymatic fibre separation and recycling of wool/polyester fabric blends. Waste Manag. 2020, 102, 149-160. [CrossRef] 
48. Roushan, M. Study on the use of fabric wastes as an energy source for boiler by incineration process. Energy Sources Part A: Recovery Util. Environ. Eff. 2021, 1-12. [CrossRef]

49. Hicks, C.; Dietmar, R.; Eugster, M. The recycling and disposal of electrical and electronic waste in China-Legislative and market responses. Environ. Impact Assess. Rev. 2005, 25, 459-471. [CrossRef]

50. Smits, H. The Time is Now for Recycled Cotton-And Here's Why. Sourc. J. 2018, 5, 89-96.

51. Kamble, Z.; Behera, B.K. Mechanical properties and water absorption characteristics of composites reinforced with cotton fibres recovered from textile waste. J. Eng. Fibers Fabr. 2020, 15. [CrossRef]

52. Popescu, V.; Astanei, D.-G.; Burlica, R.; Popescu, A.; Munteanu, C.; Ciolacu, F.; Ursache, M.; Ciobanu, L.; Cocean, A. Sustainable and cleaner microwave-assisted dyeing process for obtaining eco-friendly and fluorescent acrylic knitted fabrics. J. Clean. Prod. 2019, 232, 451-461. [CrossRef]

53. Haslinger, S.; Hummel, M.; Anghelescu-Hakala, A.; Määttänen, M.; Sixta, H. Upcycling of cotton polyester blended textile waste to new man-made cellulose fibers. Waste Manag. 2019, 97, 88-96. [CrossRef]

54. Peña-Pichardo, P.; Martínez-Barrera, G.; Martínez-López, M.; Ureña-Núñez, F.; dos Reis, J.M.L. Recovery of cotton fibers from waste Blue-Jeans and its use in polyester concrete. Constr. Build. Mater. 2018, 177, 409-416. [CrossRef]

55. Paras, M.K.; Pal, R. Application of Markov chain for LCA: A study on the clothes 'reuse' in Nordic countries. Int. J. Adv. Manuf. Technol. 2018, 94, 191-201. [CrossRef]

56. Norris, L. Recycling Indian Clothing: Global Contexts of Reuse and Value; Indiana University Press: Bloomington, IN, USA, 2010.

57. Russell, S.; Swan, P.; Trebowicz, M.; Ireland, A. Review of Wool Recycling and Reuse, in Natural Fibres: Advances in Science and Technology Towards Industrial Applications; Springer: Berlin/Heidelberg, Germany, 2016; pp. 415-428.

58. Luiken, A.; Bouwhuis, G. Recovery and recycling of denim waste. Denim 2015, 5, 527-540. [CrossRef]

59. Gam, H.J.; Cao, H.; Bennett, J.; Helmkamp, C.; Farr, C. Application of design for disassembly in men's jacket: A study on sustainable apparel design. Int. J. Cloth. Sci. Technol. 2011, 23, 83-94.

60. Janigo, K.A.; Wu, J.; Delong, M. Redesigning Fashion: An Analysis and Categorization of Women's Clothing Upcycling Behavior. Fash. Pract. 2017, 9, 254-279. [CrossRef]

61. Binotto, C.; Lunn, C.V. Silk purse, sow's ear: Transforming second-hand clothing into luxury fashion through craft practice. Mak. Futures J. 2014, 3, 311-324.

62. Broega, A.C.; Jordão, C.; Martins, S.B. Textile Sustainability: Reuse of Clean Waste from the Textile and Apparel Industry; IOP Publishing: Bristol, UK, 2017.

63. Van Lunn, C.; Binotto, C. Trashtopia by Maison Briz Vegas. Trashtopia Maison Briz Vegas 2014, 6, 56-74.

64. Binotto, C.; Payne, A. The Poetics of Waste: Contemporary Fashion Practice in the Context of Wastefulness. Fash. Pract. 2017, 9, 5-29. [CrossRef]

65. de Morais, A.S.A.; Hoeckesfeld, L.; Sarquis, A.B.; Mussi, C.C. Omnichannel as strategy of innovation in youth fashion retail industry in Brazil. REMark 2019, 18, 268.

66. Dias, M.; Aylmer, R.; Almeida, R.; Bulegon, M. Brazilian Fashion Business Dudalina S/A: Case Revisited. International Journal of Business and Management Studies. ISSN 2015, 2158, 11-24.

67. Miotto, A.P.; Parente, J.G. Retail evolution model in emerging markets: Apparel store formats in Brazil. Int. J. Retail. Distrib. Manag. 2015, 43, 242-260. [CrossRef]

68. Norup, N.; Pihl, K.; Damgaard, A.; Scheutz, C. Replacement rates for second-hand clothing and household textiles A survey study from Malawi, Mozambique and Angola. J. Clean. Prod. 2019, 235, 1026-1036. [CrossRef]

69. 조은주. Consideration on 'Redesign' in Fashion Industry Through Case Studies. J. Korea Fash. E Costume Des. Assoc. 2011, 13, 105-116.

70. Farrant, L.; Olsen, S.I.; Wangel, A. Environmental benefits from reusing clothes. Int. J. Life Cycle Assess. 2010, 15, 726-736. [CrossRef]

71. Yang, N. Empirical study on building reuse station for clothes waste disposal in Japan. J. Reg. Stud. Dev. 2011, 20, 439-456.

72. Peiró, L.T.; Polverini, D.; Ardente, F.; Mathieux, F. Advances towards circular economy policies in the EU: The new Ecodesign regulation of enterprise servers. Resour. Conserv. Recycl. 2020, 154, 104426. [CrossRef]

73. Semba, T.; Sakai, Y.; Ishikawa, M.; Inaba, A. Greenhouse Gas Emission Reductions by Reusing and Recycling Used Clothing in Japan. Sustainability 2020, 12, 8214. [CrossRef]

74. Amaral, M.C.d.; Zonatti, W.F.; Silva, K.L.D.; Karam, D.; Amato, J.; Baruque-Ramos, J. Industrial textile recycling and reuse in Brazil: Case study and considerations concerning the circular economy. Gestão Produção 2018, 25, 431-443. [CrossRef]

75. Young-Hee, P. The effect of eco-friendly behaviors and attitudes on behaviors of clothing recycling: Focused on UK, China, Korea. Res. J. Costume Cult. 2016, 24, 336-348.

76. van Bommel, H.; Goorhuis, M. Design jeans for recycling: A supply chain case study in The Netherlands. Waste Manag. Res. 2014, 32, 1142-1144. [CrossRef]

77. Koch, K.; Domina, T. Consumer Textile Recycling as a Means of Solid Waste Reduction. Fam. Consum. Sci. Res. J. 1999, $28,3-17$. [CrossRef]

78. Saha, K.; Dey, P.K.; Papagiannaki, E. Implementing circular economy in the textile and clothing industry. Bus. Strat. Environ. 2021, 30, 1497-1530. [CrossRef] 
79. Liu, J.; Liang, J.; Ding, J.; Zhang, G.; Zeng, X.; Yang, Q.; Zhu, B.; Gao, W. Microfiber pollution: An ongoing major environmental issue related to the sustainable development of textile and clothing industry. Environ. Dev. Sustain. 2021, 23, 11240-11256. [CrossRef]

80. Kim, I.; Jung, H.J.; Lee, Y. Consumers' Value and Risk Perceptions of Circular Fashion: Comparison between Secondhand, Upcycled, and Recycled Clothing. Sustainability 2021, 13, 1208. [CrossRef]

81. Avadanei, M.; Olaru, S.; Ionescu, I.; Florea, A.; Curteza, A.; Loghin, E.-C.; Dulgheriu, I.; Radu, D.C. Clothing development process towards a circular model. Ind. Text. 2021, 72, 89-96. [CrossRef]

82. Stanescu, M.D. State of the art of post-consumer textile waste upcycling to reach the zero waste milestone. Environ. Sci. Pollut. Res. 2021, 28, 14253-14270. [CrossRef] [PubMed]

83. Degenstein, L.M.; McQueen, R.H.; Krogman, N.T. ‘What goes where'? Characterizing Edmonton's municipal clothing waste stream and consumer clothing disposal. J. Clean. Prod. 2021, 296, 126516. [CrossRef]

84. Paço, A.; Filho, W.L.; Ávila, L.V.; Dennis, K. Fostering sustainable consumer behavior regarding clothing: Assessing trends on purchases, recycling and disposal. Text. Res. J. 2021, 91, 373-384. [CrossRef]

85. Koszewska, M. Circular Economy-Challenges for the Textile and Clothing Industry. Autex Res. J. 2018, 18, 337-347. [CrossRef]

86. Kant Hvass, K. Post-retail responsibility of garments-A fashion industry perspective. J. Fash. Mark. Manag. 2014, 18, 413-430. [CrossRef]

87. Harding, C.; Van Loon, J.; Moons, I.; De Win, G.; Du Bois, E. Design Opportunities to Reduce Waste in Operating Rooms. Sustainability 2021, 13, 2207. [CrossRef]

88. Vehmas, K.; Raudaskoski, A.; Heikkilä, P.; Harlin, A.; Mensonen, A. Consumer attitudes and communication in circular fashion. J. Fash. Mark. Manag. Int. J. 2018, 22, 286-300. [CrossRef]

89. Oncioiu, I.; Ifrim, A.M.; Petrescu, M.; Petrescu, A.G.; Petcu, C.; Silvestru, C.I. Considerations regarding the purchase behaviour for clothes made from recycled textile waste in Turkey. Ind. Text. 2021, 72, 97-101. [CrossRef]

90. Subramanian, K.; Chopra, S.S.; Cakin, E.; Li, X.; Lin, C.S.K. Environmental life cycle assessment of textile bio-recycling-valorizing cotton-polyester textile waste to pet fiber and glucose syrup. Resour. Conserv. Recycl. 2020, 161, 104989. [CrossRef]

91. Trajković, D.; Jordeva, S.; Tomovska, E.; Zafirova, K. Polyester apparel cutting waste as insulation material. J. Text. Inst. 2017, 108, 1238-1245. [CrossRef]

92. Sakthivel, S.; Melese, B.; Edae, A.; Abedom, F.; Mekonnen, S.; Solomon, E. Garment Waste Recycled Cotton/Polyester Thermal and Acoustic Properties of Air-Laid Nonwovens. Adv. Mater. Sci. Eng. 2020, 2020, 8304525. [CrossRef]

93. Nayak, R.; Houshyar, S.; Patnaik, A.; Nguyen, L.T.; Shanks, R.A.; Padhye, R.; Fegusson, M. Sustainable reuse of fashion waste as flame-retardant mattress filing with ecofriendly chemicals. J. Clean. Prod. 2020, 251, 119620. [CrossRef]

94. Çay, A.; Yanık, J.; Akduman, C.; Duman, G.; Ertaş, H. Application of textile waste derived biochars onto cotton fabric for improved performance and functional properties. J. Clean. Prod. 2020, 251, 119664. [CrossRef]

95. Lin, C.-W.R.; Chen, M.T.; Tseng, M.-L.; Jantarakolica, T.; Xu, H. Multi-Objective Production Programming to Systematic Sorting and Remanufacturing in Second-Hand Clothing Recycling Industry. Symmetry 2020, 12, 1161. [CrossRef]

96. Leonas, K.K. The Use of Recycled Fibers in Fashion and Home Products. In Textiles and Clothing Sustainability. Textile Science and Clothing Technology; Muthu, S., Ed.; Springer: Singapore, 2017; pp. 55-77. [CrossRef]

97. Chen, X.; Geng, Y.; Fujita, T. An overview of municipal solid waste management in China. Waste Manag. 2010, 30, 716-724. [CrossRef]

98. Payne, A. Open-and closed-loop recycling of textile and apparel products. In Handbook of Life Cycle Assessment (LCA) of Textiles and Clothing; Elsevier: Amsterdam, The Netherlands, 2015; pp. 103-123.

99. Nixon, H.; Saphores, J.-D.M. Information and the decision to recycle: Results from a survey of US households. J. Environ. Plan. Manag. 2009, 52, 257-277. [CrossRef]

100. Conke, L.S. Barriers to waste recycling development: Evidence from Brazil. Resour. Conserv. Recycl. 2018, 134, 129-135. [CrossRef]

101. Jesson, J.; Pocock, R.; Stone, I. Barriers to Recycling: A Review of Evidence since 2008; The Waste \& Resources Action Programme: Banbury, UK, 2014.

102. Anthouli, A.; Aravossis, K.; Charitopoulou, R.; Tot, B.; Vujic, G. Opportunities E Barriers of Recycling in Balkan Countries: The Cases of Greece and Serbia; HSWMA: Athens, Greece; SeSWA: Tallahassee, FL, USA; ISWA: Rotterdam, The Netherlands, 2013.

103. Xiao, S.; Dong, H.; Geng, Y.; Brander, M. An overview of China's recyclable waste recycling and recommendations for integrated solutions. Resour. Conserv. Recycl. 2018, 134, 112-120. [CrossRef] 